\title{
Multimodal Art Therapy for Overcoming Negative Emotional States among Adolescents
}

\author{
Anastasia V. Mishina ${ }^{1}$, Juliya L. Blinova*2, Olga G. Belomoyeva ${ }^{3}$ \\ ${ }^{1,2}$ Kazan Federal University, Kazan, Tatarstan, Russia, \\ ${ }^{3}$ National Research Mordovian State University N.P. Ogaryova \\ ${ }^{* 2}$ E-mail:julorblinova@mail.ru
}

\section{Received: 21st October 2017 Accepted: 16th November 2017, Published: 31st December 2017}

\begin{abstract}
Psychological and pedagogical support for schoolchildren during the adolescent age crisis is acute social problem today. Over the past 2016, the number of attempts of adolescent suicide has increased 1.5 times. The number of teenagers, which have computer and game addiction, is constantly growing, the number of schoolchildren, demonstrating aggressive antisocial behavior, remains at a high level.

The purpose of this study was to develop a program to overcome negative emotional states of adolescents, using multimodal art therapy.

The choice of multimodal art therapy, as a means of overcoming communicative barriers, was determined by its orientation on acquiring a variety of sensory and communicative experiences by participants, through the use of artistic, creative and play activities.

The methods of theoretical scientific cognition were used in the process of research. They allowed to distinguish the characteristics of negative emotional state in adolescents (the level of personal anxiety, the level of aggression, the presence of suicidal risk, the feeling of chronic fatigue, and the difficulties in interacting with adults and peers).

The result of investigation was the program to overcome the negative emotional state of adolescents, using multimodal art therapy. Approbation of the developed program revealed its effectiveness as one of the possible forms of psychological and pedagogical support of schoolchildren during the adolescent crisis.
\end{abstract}

Keywords: Adolescent Crisis, Negative Emotional States, Addictive Behavior, Deviant Behavior, Teenage Suicide, Multimodal Art Therapy, Art, NonVerbal Interaction, Artistic and Creative Activity.

\section{Introduction}

The need for psychological and pedagogical support of schoolchildren, experiencing the adolescent age crisis is, at the moment, the most acute problem of the modern Russian socio-cultural and educational reality.

Children's ombudsman Anna Kuznetsova had voiced the statistics of adolescent suicides at the conference call "On the Prevention of Juvenile Suicides", held in the National Center for Crisis Management of the
Ministry of Emergency Situations of Russia: "From 2011 to 2015, the number of suicides in the country steadily decreased by $10 \%$ per year. But in 2016 there is an increase by $57 \%$. We drastically rolled back for five years "[4].

Among the objective factors, determining this situation are the following: multi-aspect (social and economic, political, educational, etc.) instability of the surrounding world, the expansion and accessibility of modern technologies, forming destructive communities and the "death cult" (virtual" death groups"), the decrease of interest in the outside world and loss of value of real interaction with the surrounding reality, lack of available qualified psychological support in educational institutions, insufficient involvement of the family in the life of teenager.

In the process of analysis of existing Russian research in this field (V. Averin, A. Ambrumova, V. Efremov, I. Kon, A. Mikhailina, N. Mokhovikov, P. Murzabaeva, I. Pogodin, A. Samygin, V. Tregubov, Yu. Fisin, et al.), the main internal causes of destructive behavior of adolescents were identified, namely:

1. Acute emotional experience of self-uniqueness, superimposed on a pronounced feeling of selfimperfection and insolvency;

2. Feeling of social and psychological isolation and loneliness (misunderstanding and rejection by peers, parents and teachers);

3. High level of personal anxiety and frustration;

4. Impossibility of realization of positive emotionalvalue interpersonal interaction;

5. Reappraisal of values and the formation of own worldview, moral and cultural attitudes;

6. Pessimism, associated with the own social future and making of constructive plans;

7. Desire to be accepted and recognized, to meet the group of like-minded people.

All these inner emotional experiences of the adolescent lead to the emergence of a stable discomfort, characterized by marked negativism and aggression, going to virtual or imaginary reality (including under the influence of alcohol, narcotic and psychotropic drugs), the appearance of suicidal thoughts and moods, deviant behavior.

Thus, a stable negative emotional state causes the occurrence of affective emotions, destructive thoughts, as well as deviant, addictive and suicidal behavior of adolescents. 
In the process of development of generalized concept of this study, we selected the characteristics of negative emotional state of adolescents, on the basis of which, a diagnostic package of techniques was subsequently formed. The investigated characteristics were the following: the level of personal anxiety; subjective feeling of loneliness and isolation; readiness for constructive interaction; level of working capacity (or a feeling of chronic fatigue); availability of internal resources to overcome stressful situations.

The purpose of our research was to identify the potential of multimodal art therapy technologies in overcoming the negative emotional states of teenagers.

In accordance with the goal, the following tasks were specified:

1. Creation of a safe psychological space for the manifestation of "ego" of every teenager.

2. Creation of pedagogical situations for delegation the part of authority to the adolescents for managing the group, in order to increase self-esteem and group status among peers.

3. Improvement of skills of recognition and selfregulation of emotional states.

4. Development of extra-curricular activities, contributing to the formation of skills for overcoming conflicts and gaining the experience of constructive interaction between all participants.

5. Expanding the range of cultural and aesthetic perception of reality.

\section{Materials and Methods}

In our opinion, the multimodal approach in art therapy is the most adequate for achievement of the goals, stated in the introduction, and optimal in the field of solution the tasks.

Multimodal approach in art therapy (I. Shenkel, I.V.Biryukova, E.V. Burenkova) is a complex methodology, combining 3 branches of non-directive art therapy [1]:

1. Expressive Arts Therapy (P.Knill, S. McNiff, S. Levin), the main focus of which is directed on the realization of "What and Howdo you do";

2. Person-centered approach, based on expressive arts (N. Rogers [9]), whose main focus is directed on emotional experiencing and feeling (What do you feel);

3. Phenomenological approach in art therapy (M. Betensky), the central aspect of which is the way from the description of the created art object to the feeling and meeting with the stories (What do you see).

Decisive in the choice of research methodology were the following provisions of the multimodal approach in art therapy:

1. A person in his life is able to hear, see, move; therefore, it is natural for him to express himself using all these sense organs and modalities of arts [8];

2. In the concept of multimodal art therapy, the modalities of imagination are movement, sound, image, rhythm, word, action. The modalities of imagination -are the ways of communication with the world, "to see" what and how we live (P. Knill, BarbaKh.N. , Fuks M.N. [8]). The more modalities of imagination are used, the more vivid and meaningful is self-expression, the more adequate the form and content of communication [7].

3. Relationships - the most important factor in therapy, counseling and support (G. Eberhart). Professional relations in the process of psychological support presuppose the obligatory creation of a safe, supportive, open, respectful, non-judgmental environment. Not a method, but a relationship treats and helps to cope with problems (I.Shenkel).

4. P. Knill [8] says, that the direction of Expressive Arts Therapy is a "playground for adults", where creative activity in the space of art is a kind of game with materials and expressive means of art, in a specially organized space-time ("frame").

5. Use in the multimodal approach of gaming methods, in particular, components of games, defined by D.W. Winnicott [2], focused on the quality of the process and the study of their individual capabilities and limitations (plays), and aimed at achieving results, and as a consequence, improving selfdiscipline, self-esteem, self-confidence (games).

6. The presence of "transitional" space (D.W.Winnicott), where the patterns of intrapsychic frame works of functioning and interaction of a person with the world are formed, in the process of creative activity, in different modalities of art.

7. The interaction of psychological and artistic processes is the ground, on which anxiety and new possibilities for understanding, change and healing are investigated [6].

Thus, the working hypothesis of our study is the assumption, that the creation of a secure, nonjudgmental space, where trustful respectful relationships between adults and adolescents are built up, rules of interaction are discussed together, and creative activity is carried out, using various modalities and components of gaming activities, will help to prevent the emergence and overcoming of negative emotional states of adolescents.

The study is based on the use of theoretical methods of scientific knowledge, the study of literature, the use of valid diagnostic methods.

\section{Results}

16 teenagers of school age took part in the study. Monitoring of the study included 2 stages: preliminary (pilot study) and final diagnostics.

The diagnostic package for the preliminary diagnostics contained the following methodologies:

1. Questionnaire "Study of anxiety" of Ch.D. Spielberger;

2. The aggressiveness test (Questionnaire of L.G.Pochebut);

3. Screening diagnostics of computer addiction (L.N.Yurieva, T. Yu. Bolbot);

The final diagnostic complex included: 
1. "Questionnaire of suicidal risk" (modification of T.N.Razuvaeva);

2. "Methods of diagnosing the level of subjective feelings of loneliness" by D. Russell and M. Ferguson.

3. The questionnaire "Losses and acquisitions of personal resources" (N. Vodopyanova, M. Stein);

4. Questionnaire "Degree of chronic fatigue" A.B. Leonova.

According to the results of pilot experiment, 11 adolescents had a high level of anxiety, 4 teenagers were seen in the demonstration of aggressive behavior, 2 teenagers had computer game addiction, 8 adolescents had some difficulties in their relationships with peers, 5 teenagers indicated the existing difficulties in relationships with their families.

\section{Discussion}

The obtained results confirm the findings of the studies of V. Averin, A. Ambromova, I. Pogodin, A. Samygin, and others on the unfavorable emotional state of modern adolescents and the need for psychological and pedagogical support for adolescent schoolchildren. Based on the above results of the study of emotional states and problematic relations of teenage schoolchildren, we have developed and tested the program "Ego Laboratory", which helped to overcome the negative emotional states of adolescents.

The basis for the implementation of the program "Ego Laboratory" is the art analogy of "Quest", as a means of finding a way out of a difficult situation, by performing non-scripted game actions, finding unexpected creative solutions, acquiring a new sensory and communicative experience.

The basis for the selection of this art-analogy was the characteristics of the game genre "quest". In English "quest" means "search, execution of instructions". As a game genre, it initially involves the execution of tasks, which are impossible to be done without the manifestation of creativity, bold, unexpected decisions, and the search for an optimal strategy for the way out. The main peculiarity of the quest game is the impossibility of its continuation without solving the next task and the execution of all coded rules.

The use of art-analogy of the game-quest allowed to achieve the goals of the program in the form of a game:

1. Creation of conditions for the manifestation of individuality and activity of each participant.

2. Ability to make decisions and bear responsibility for them.

3. Increased stress resistance and self-regulation of emotional states.

4. Formation of group cohesion through understanding the need for compliance with rules, acquiring experience in conflict resolution.

5. Actualization of creativity as a means to find a way out in unforeseen situations.

The names of the stages, their content and form of the used art-technologies are presented in Table 1.

Table 1 Plan of the Art-action in the Framework of the Art Analogy "Quest "Secret Laboratory"

\begin{tabular}{|c|c|c|c|c|}
\hline $\begin{array}{l}\text { The stage } \\
\text { of the lesson, } \\
\text { function }\end{array}$ & Subject & Purpose & $\begin{array}{c}\text { Modalityofima } \\
\text { gination }\end{array}$ & Content of the art-action \\
\hline Session start & Greetings & Acquaintance & Movement & $\begin{array}{l}\text { Introduction in a circle (Ball + } \\
\text { "Name Today") }\end{array}$ \\
\hline \multirow{6}{*}{$\begin{array}{l}\text { Sessionstart, } \\
\text { Working in }\end{array}$} & $\begin{array}{l}\text { Studying of game } \\
\text { space }\end{array}$ & $\begin{array}{l}\text { "Revival", awakening } \\
\text { of the body }\end{array}$ & Movement & $\begin{array}{l}\text { Getting to know the space } \\
\text { (different qualities of motion, } \\
\text { touching different surfaces with } \\
\text { different parts of the body) }\end{array}$ \\
\hline & Safety instructions & $\begin{array}{l}\text { Formation of group } \\
\text { rules of behavior and } \\
\text { interaction }\end{array}$ & Word, image & $\begin{array}{l}\text { Formulation of basic rules and their } \\
\text { symbolic images }\end{array}$ \\
\hline & $\begin{array}{l}\text { Learning how to } \\
\text { move }\end{array}$ & $\begin{array}{l}\text { Synchronization of the } \\
\text { group }\end{array}$ & $\begin{array}{l}\text { Movement, } \\
\text { rhythm }\end{array}$ & $\begin{array}{l}\text { Follow upon... (repeat the } \\
\text { movements for the first in the chain } \\
\text { (direction, activity, rhythm) }\end{array}$ \\
\hline & & & & \\
\hline & $\begin{array}{l}\text { «Traps and tight } \\
\text { corners» }\end{array}$ & $\begin{array}{c}\text { Sensomotor } \\
\text { coordination, } \\
\text { enhancement of } \\
\text { interhemispheric } \\
\text { interaction }\end{array}$ & Movement & $\begin{array}{l}\text { Variants of movement: } \\
\text { Slip on the floor, move in an } \\
\text { unusual way, jump, etc. }\end{array}$ \\
\hline & "The Mirror & $\begin{array}{c}\text { Development of } \\
\text { kinesthetic empathy, } \\
\text { non-verbal interaction }\end{array}$ & Movement & $\begin{array}{l}\text { The technique of "Mirror", } \\
\text { "Carousel" }\end{array}$ \\
\hline
\end{tabular}


Helix Vol. 8(1): $2307-2311$

\begin{tabular}{|c|c|c|c|c|}
\hline \multirow[t]{2}{*}{ Main part } & Room" & \multicolumn{3}{|l|}{$\begin{array}{l}\text { skills, synchronization } \\
\text { with a partner }\end{array}$} \\
\hline & "What'sinmyhead" & $\begin{array}{c}\text { Understanding of } \\
\text { motives, available } \\
\text { resources, prioritization }\end{array}$ & Image (collage) & $\begin{array}{l}\text { Drawing a contour of the future } \\
\text { hairstyle (in real scale) and filling } \\
\text { with images, found and cut out } \\
\text { from magazines }\end{array}$ \\
\hline \multirow{6}{*}{$\begin{array}{l}\text { Main part } \\
\text { CREATIVE } \\
\text { ACTIVITIES }\end{array}$} & "Waterfall" & $\begin{array}{l}\text { Understanding the need } \\
\text { for crises }\end{array}$ & $\begin{array}{l}\text { Movement, } \\
\text { image, word }\end{array}$ & $\begin{array}{l}\text { Moving around a large space, } \\
\text { covered with paper, outlining the } \\
\text { contours of a neighbor's body and } \\
\text { finding "precious stones", creating } \\
\text { a group history }\end{array}$ \\
\hline & "Signsontheway" & \multirow{3}{*}{$\begin{array}{l}\text { Searching and } \\
\text { activation of resource }\end{array}$} & Image (iso) & $\begin{array}{c}\text { Drawing by not dominant arm on a } \\
\text { colored sheet of paper, using ink } \\
\text { and Chinese sticks }\end{array}$ \\
\hline & "Dactyloscopy" & & Image & $\begin{array}{l}\text { Art technology "Hand hindering - } \\
\text { hand helping" }\end{array}$ \\
\hline & «Rest break» & & $\begin{array}{l}\text { Image (iso- } \\
\text { sounding- } \\
\text { movement) }\end{array}$ & $\begin{array}{c}\text { Relaxation (music }+ \text { text) }- \text { then the } \\
\text { work with resource images from } \\
\text { natural materials }\end{array}$ \\
\hline & $\begin{array}{l}\text { "From the life of the } \\
\text { camp" }\end{array}$ & $\begin{array}{l}\text { Understanding of own } \\
\text { social roles, interaction } \\
\text { patterns, development } \\
\text { of new strategies }\end{array}$ & $\begin{array}{l}\text { Action } \\
\text { (theater) }\end{array}$ & $\begin{array}{l}\text { Participant of the group is the stage } \\
\text { director, who sets the scene from } \\
\text { the life of the camp }\end{array}$ \\
\hline & «Gruesomesstories» & Searchfornewmeanings & Poetry & $\begin{array}{l}\text { Collective tale in the form of a } \\
\text { rondo }\end{array}$ \\
\hline \multirow{3}{*}{$\begin{array}{l}\text { Finish } \\
\text { "Harvestingfruit } \\
\qquad \text { s" }\end{array}$} & «Amulet» & \begin{tabular}{|c|} 
Comprehension of \\
experience (what are my \\
conclusions, what I will \\
take with me)
\end{tabular} & $\begin{array}{c}\text { Image (plastic- } \\
\text { and natural } \\
\text { materials) }\end{array}$ & $\begin{array}{l}\text { Making amulets from the mass for } \\
\text { modeling with decorative elements }\end{array}$ \\
\hline & "Hooray! Victory" & Groupingtogether & \begin{tabular}{|c|} 
Clay, \\
decorativeelem \\
ents
\end{tabular} & $\begin{array}{c}\text { Handing of cups and valuable } \\
\text { prizes }\end{array}$ \\
\hline & $\begin{array}{c}\text { «Sharingimpression } \\
\text { S» }\end{array}$ & $\begin{array}{c}\text { Callback } \\
\text { fromparticipants }\end{array}$ & Word & $\begin{array}{l}\text { Message to next person (making } \\
\text { mini-cards with wishes in the } \\
\text { scrapbooking technique) }\end{array}$ \\
\hline
\end{tabular}

\section{Conclusions}

The results of this investigation allow to draw the following conclusions:

1. Individual and group creative activity in safe non-judgmental space on tributes to overcoming the actual negative states, to searching for new internal resources in difficult situations; reduces the level of anxiety and aggressiveness.

2. The use of multimodal approach in the art therapy opens up new opportunities for the support of teenagers in the field of overcoming negative emotional states through the use of playing and gaming components, within the framework of artistic and creative activity, in various branches of art.

3. The results of the study showed positive dynamics in the correction of negative emotional states of adolescents, causing the appearance of affective emotions, destructive thoughts, as well as deviant, addictive and suicidal behavior of adolescents.

4. At the same time, it can be noted the need to develop a program for teachers and psychologists, who carry out psychological and pedagogical support for adolescent schoolchildren, aimed at increasing their competence in art, to strengthen the effectiveness of the developed program. We agree with I.G. Batyrshina and L.G.Safiullina, who believe, that "the artistic universalism of the individual implies a multiplicity of thinking, the desire to manifest himself in different types of art and even science, to discover new horizons in the world learning" [10]. In this aspect, only a teacher, who is all-round in the field of art, is able to realize supportive relationships with adolescents, using a multimodal approach in art therapy. 


\section{Acknowledgements}

The work is performed according to the Russian Government Program of Competitive Growth of Kazan Federal University.

\section{References}

[1] Burenkova E.V. Multimodality in Art Therapy: methodology // Art therapy: Intermodal approach (Expressive Arts Therapy): Collection of articles of the VI International Festival of Intermodal Therapy with the arts "Mir-O-Tvorchestvo", June 2-4, 2017/ Edited by E.V. Burenkova, V.V.Sidorova. - Penza: IESokolovA.Yu., 2017. - Pp.92-113.

[2] Winnicott D.W. Game and reality. - Moscow: Publishing House "Institute of General Humanitarian Research", 2002.

[3] Zhirkova I.S., Sergeeva E.D. The interrelation between the propensity for Internet addiction and the level of importance of the other people attitude in adolescents and young males// Modern psychology of education: problems and perspectives. The materials of all-Russian (with international participation) scientific-practical conference. - Voronezh, 2016. Pp.86-89.

[4] N. Andreeva. Terrible statistics // http://wordyou.ru/236899-strashnaya-statistikachislo-detskix-suicidov-v-rossii-v-2016-goduvyroslo-pochti-na-60\%E2\%80\%8D.html. (Date of access 11.05.2017).

[5] Rogers N. Creative connection. The healing power of expressive arts. - M: Mann, Ivanov and Ferber, 2015.- 336p.

[6] Halprin D.The Exspressive Body in Life, Art andTherapy. - Jessica Kingsley Publisher, London and Fhiladelphia,2003.

[7] Isekeeva S.V., Blinova J.L., Yavgildina Z. M. Multimodal art therapy to overcome communication difficulties among preschoolers. // The Turkish Online Journal of Design, Art and Communication (TOJDAC), November 2016 Special Edition (DOI: 10.7456/1060NVSE).

[8] Paolo J. Knill, Helen N. Barba, Margo N. Fuchs "MinistrelsofSoul" Intermodal Expressive Therapy, Toronto, Palmeston Press, 1993.
[9] Rogers
$\mathrm{N}$.
CreativeConnection.

PoloAltoScience\&BehaviorBooks, Inc., 1993.

[10] Safiullina L.G., Batyrshina G.I. Musical images as a reflection of the artistic universalism of Marc Chagall// Terra Sebus: ActaMuseiSabesiensis. - 2014. - Special Issue. - Pp. 67-104. 